\title{
Comparison of Anti-Oxidative Effect of Human Adipose- and Amniotic Membrane-Derived Mesenchymal Stem Cell Conditioned Medium on Mouse Preimplantation Embryo Development
}

\author{
Kihae Ra ${ }^{1}$, Hyun Ju Oh ${ }^{1,2}$, Eun Young Kim ${ }^{3}$, Sung Keun Kang ${ }^{3}{ }^{\mathbb{D}}$, Jeong Chan $\operatorname{Ra}^{3}$, Eui Hyun Kim ${ }^{1}{ }^{\mathbb{D}}$, \\ Se Chang Park ${ }^{4, *}$ and Byeong Chun Lee ${ }^{1, *}$ \\ 1 Department of Theriogenology and Biotechnology, College of Veterinary Medicine, Seoul National University, \\ Seoul 08826, Korea; ragh1102@snu.ac.kr (K.R.); ohj@mkbiotech.co.kr (H.J.O.); hyun9214@snu.ac.kr (E.H.K.) \\ 2 Research and Development Center, MKbiotech Co., Ltd., 99 Daehak-ro, Daejeon 34134, Korea \\ 3 Biostar Stem Cell Research Institute, R Bio Co., Ltd., Seoul 08506, Korea; naraokke@stemcellbio.com (E.Y.K.); \\ kangsk@stemcellbio.com (S.K.K.); jcra@stemcellbio.com (J.C.R.) \\ 4 Laboratory of Aquatic Biomedicine, College of Veterinary Medicine, Seoul National University, \\ Seoul 08826, Korea \\ * Correspondence: parksec@snu.ac.kr (S.C.P.); bclee@snu.ac.kr (B.C.L.)
}

Citation: Ra, K.; Oh, H.J.; Kim, E.Y.; Kang, S.K.; Ra, J.C.; Kim, E.H.; Park, S.C.; Lee, B.C. Comparison of Anti-Oxidative Effect of Human Adipose- and Amniotic

Membrane-Derived Mesenchymal Stem Cell Conditioned Medium on Mouse Preimplantation Embryo Development. Antioxidants 2021, 10, 268. https://doi.org/10.3390/ antiox10020268

Academic Editor: Ana Sofia Fernandes

Received: 10 January 2021

Accepted: 5 February 2021

Published: 9 February 2021

Publisher's Note: MDPI stays neutral with regard to jurisdictional claims in published maps and institutional affiliations.

Copyright: (c) 2021 by the authors. Licensee MDPI, Basel, Switzerland. This article is an open access article distributed under the terms and conditions of the Creative Commons Attribution (CC BY) license (https:/ / creativecommons.org/licenses/by/ $4.0 /)$.

\begin{abstract}
Oxidative stress is a major cause of damage to the quantity and quality of embryos produced in vitro. Antioxidants are usually supplemented to protect embryos from the suboptimal in vitro culture (IVC) environment. Amniotic membrane-derived mesenchymal stem cells (AMSC) have emerged as a promising regenerative therapy, and their paracrine factors with anti-oxidative effects are present in AMSC conditioned medium (CM). We examined the anti-oxidative potential of human AMSC-CM treatment during IVC on mouse preimplantation embryo development and antioxidant gene expression in the forkhead box O (FoxO) pathway. AMSC-CM (10\%) was optimal for overall preimplantation embryo developmental processes and upregulated the expression of FoxOs and their downstream antioxidants in blastocysts (BL). Subsequently, compared to adiposederived mesenchymal stem cell (ASC)-CM, AMSC-CM enhanced antioxidant gene expression and intracellular GSH levels in the BL. Total antioxidant capacity and SOD activity were greater in AMSC-CM than in ASC-CM. Furthermore, SOD and catalase were more active in culture medium supplemented with AMSC-CM than in ASC-CM. Lastly, the anti-apoptotic effect of AMSC-CM was observed with the regulation of apoptosis-related genes and mitochondrial membrane potential in BL. In conclusion, the present study established AMSC-CM treatment at an optimal concentration as a novel antioxidant intervention for assisted reproduction.
\end{abstract}

Keywords: adipose-derived mesenchymal stem cell; amniotic membrane-derived mesenchymal stem cell; antioxidants; assisted reproductive technology; conditioned medium; embryo; in vitro culture; in vitro fertilization; oxidative stress

\section{Introduction}

The success rate of assisted reproductive technologies (ART) to surmount infertility has increased with the improvement of conditions for embryo in vitro production [1]. The balance of reactive oxygen species (ROS) and antioxidants is maintained at physiologically normal levels in female reproductive systems, but is disrupted in vitro, resulting in an increase in exposure to oxidative damage risk [2]. In the process of assisted reproduction, a number of external factors causing oxidative stress appear from technical procedures to environmental sources [3]. Subsequently, oxidative stress due to accumulated ROS in in vitro-produced embryos impairs the efficiency of embryonic development and induces reproductive failure due to an increase in embryo fragmentation and apoptosis, and a 
decrease in fertilization rate and blastocyst (BL) development [4-6]. Accordingly, the application of antioxidants to ART can be an effective intervention to counteract the oxidative damage in in vitro-produced embryos [7], especially to improve the in vitro culture (IVC) medium for favorable outcomes in preimplantation embryo development. Accumulating studies have indicated that the addition of antioxidants to IVC medium improves preimplantation embryo development by regulating the embryonic environment and protecting embryos from oxidative damage [8-11], which leads to the decrease in developmental competence of embryos produced in vitro compared to that of embryos developed in vivo [12].

Mesenchymal stem cells (MSCs) are known to ameliorate oxidative stress through the upregulation of enzymatic antioxidants [13]. MSCs isolated from multiple tissue sources have common but various features, which emphasize their importance as regenerative medicine [14]. Among multiple sources, adipose-derived MSCs (ASCs) are the most widely studied, forming the basis of research on MSC-based therapy [15] and is representatively known a strong antioxidant [6,13,16-18]. Contemporarily, amniotic membrane-derived MSCs (AMSC) have emerged as a novel candidate in the field of regenerative medicine because of their unique advantages, including noninvasive isolation, stable immunogenicity, abundant availability, multipotency for all three germ layers, and no associated ethical issues [19]. The amniotic membrane is a constituent of the placenta with its essential function of nutrient supplementation and physical protection for the fetus during pregnancy, but is generally discarded post-partum and infrequently utilized compared to other MSCs [20]. However, AMSCs retain the anti-microbial, anti-tumorigenic, immunomodulatory, and anti-inflammatory characteristics of amniotic membrane [21]. Recent studies on potential therapeutic features of human AMSCs have focused on their role in immunomodulation, suppressing inflammation, and inhibiting oxidative damage [22-25]. Although diverse studies support the anti-oxidative effect of AMSCs in diseases models, the therapeutic applications of AMSCs were restricted to cell transplantation [22,26,27]. The regenerative effect of stem cell therapy is mainly facilitated by its paracrine factors, such as cytokines and growth factors, rather than by direct regenerative mechanisms $[28,29]$. These stem cell-derived paracrine factors are secreted during cell culture and are present in the stem cell-conditioned medium (CM) [30]. The therapeutic efficacy of the CM is comparable to that of the conventional cell-based therapy. Furthermore, the use of CM offers several advantages over conventional stem cell-therapy, such as improved reproducibility, no requirement to match the donors and recipients, and no risk of immune rejection [31].

In the present study, we aimed to investigate the anti-oxidative potential of AMSC$\mathrm{CM}$ and establish the optimal concentration for AMSC-CM treatment during embryo IVC. Consequently, the anti-oxidative and anti-apoptotic effects of AMSC-CM were evaluated as compared to ASC-CM in the development of mouse preimplantation embryos.

\section{Materials and Methods}

\subsection{Chemicals and Reagents}

All materials were purchased from Sigma-Aldrich (St. Louis, MO, USA), unless otherwise specified.

\subsection{Culture and Characterization of ASCs and AMSCs}

Both ASCs and AMSCs were obtained from R Bio Stem Cell Research Center under GMP conditions. All subjects gave their informed consent for inclusion before they participated in the study. The protocol was approved by the Ethics Committee of Biostar Stem Cell Technology (IRB NO. 2019-03). ASCs were cultured and characterized as previously described [6]. For the establishment of AMSCs, cryopreserved AMSCs $\left(1 \times 10^{6}\right)$ from the amnion tissue of three female donors were cultured in T-175 flasks containing RPME-P ( $R$ $\mathrm{BIO}$, Seoul, Korea) supplemented with $1 \%$ antibiotic-antimycotic solution at $37^{\circ} \mathrm{C}$ with $5 \% \mathrm{CO}_{2}$. The AMSCs were cultured in AMSC medium (R BIO) until 80-90\% confluency and non-adherent cells were discarded through medium change. The immunophenotypic 
markers of cultured AMSCs was characterized by flow cytometry. AMSCs $\left(1 \times 10^{6}\right)$ were suspended in phosphate-buffered saline (PBS) and labeled with fluorescein isothiocyanate and phycoerythrin isotype controls. The labeled cells were incubated for 30-60 min with the following antibodies against human antigens: MSC positive markers (CD73, CD90, CD105, CD29, and CD44) and negative markers (CD31, CD34, and CD45) (BD Biosciences, San Jose, CA, USA). After the cells were washed with PBS, the analysis was conducted with FACSCalibur ${ }^{\mathrm{TM}}$ flow cytometer (BD Biosciences) and CellQuest Pro software (BD Biosciences).

\subsection{Preparation of ASC-CM and AMSC-CM}

ASC-CM were collected using the same method as previously described [6]. AMSCs per donor (passage 6) were cultured in RPME-P until 90\% confluency, and then the medium was replaced to Dulbecco's modified Eagle's medium (DMEM) after washing twice with PBS. The culture medium was collected every $24 \mathrm{~h}$ and then DMEM was added to the original flask. Supernatants were collected for 5 days and then pooled. To obtain CM, the pooled supernatant was centrifuged (1700 rpm, $5 \mathrm{~min}$ ) and then filtered in a 0.22- $\mu \mathrm{m}$ filter. Lastly, filtered CM of donors was equally mixed and concentrated $10 \times$ by centrifugation at $3000 \times g$ for 90 min using a filter tube (Vivaspin 20, GE healthcare, Chicago, IL, USA).

\subsection{Experimental Animals}

All experiments using experimental animals in this study were approved by the Institutional Animal Care and Use Committee of Seoul National University (SNU-170511-24). Seven-week-old female and 10-week-old male ICR mice were purchased from Orient Bio (Gapyeong, Korea). Mice were kept in an animal facility under conventional environment with the light/dark cycle, humidity and temperature regulated.

\subsection{In Vitro Fertilization and Culture}

After cervical dislocation of mature male mice, caudal epididymides were removed and the duct of the caudal epididymis was incised. The sperm stored inside were dispersed into a droplet of CARD medium (Cosmo Bio Co., Tokyo, Japan). Sperm were incubated for an hour at $36{ }^{\circ} \mathrm{C}$ to enable capacitation. The induction of superovulation of mature female mice was conducted by an intraperitoneal injection of $10 \mathrm{IU}$ pregnant mare serum gonadotropin and human chorionic gonadotropin (hCG) after $47 \mathrm{~h}$. The cumulus-oocyte complexes (COCs) were recovered from the oviductal ampulla of the mice $16 \mathrm{~h}$ after hCG injection and transferred to a droplet of CARD medium. The sperm suspension was treated with COCs for insemination and incubated for $3 \mathrm{~h}$ at $36^{\circ} \mathrm{C}$. In vitro fertilized embryos were washed and cultured in fresh human tubal fluid (Cosmo Bio Co., Tokyo, Japan) at $36{ }^{\circ} \mathrm{C}$ for $24 \mathrm{~h}$. Embryos that cleaved to the 2- or 4-cell were randomly divided and then cultured in the groups as described in experimental design for $96 \mathrm{~h}$. The embryo development was evaluated by assessing the number of 4-cell, 16-cell, BL, and hatched BL using a stereomicroscope. The temperature was set based on the literature and our preliminary study. The literature demonstrated that slightly lower temperature could be physiologically relevant to reproductive tissues [32-34] and comparable to traditional $37^{\circ} \mathrm{C}$ for reproductive outcomes [35-37]. In our preliminary study, developmental rate to BL at $36{ }^{\circ} \mathrm{C}$ showed no difference to that at $37^{\circ} \mathrm{C}$, and both rates were observed within the normal range.

\subsection{Experimental Design}

First, fertilized embryos were cultured in continuous single culture-NX (CSCM-NX; FUJIFILM Irvine Scientific, Santa Ana, CA, USA) containing 10\%, 20\%, and 50\% (v/v) AMSC-CM. After determining the optimal concentration of AMSC-CM for IVC supplementation, embryos were cultured followed by in vitro fertilization in CSCM-NX containing ASC-CM or AMSC-CM. The optimal concentration of ASC-CM was set $5 \%(v / v)$ as pre- 
viously reported [6]. The control group was cultured in CSCM-NX medium without CM supplementation.

\subsection{Quantitative Reverse Transcription-Polymerase Chain Reaction (qRT-PCR)}

RNA was extracted from BLs using an RNAqueous ${ }^{\mathrm{TM}}{ }_{-}$Micro Total RNA Isolation Kit (Ambion, Austin, TX, USA), according to the manufacturer's instructions. The concentration of extracted total RNA was quantified by a NanoDrop 2000 Spectrophotometer (Thermo Fisher Scientific, Wilmington, DE, USA) and presented in Table S1. Using the RNA, complementary DNA (cDNA) was synthesized by a Maxime RT premix kit (iNtRON, Gyeonggi, Korea). qRT-PCR was carried out using a StepOnePlus Real-Time PCR System (Applied Biosystems, Foster City, CA, USA) and the protocol in detail was previously described [18]. The expression of target genes was measured and normalized relative to the control house-keeping gene, 18S rRNA [38-40]. The gene expression values were calculated as previously described [18]. The list of primers is presented in Table 1.

Table 1. List of primer and sequence used for quantitative reverse transcription-polymerase chain reaction.

\begin{tabular}{|c|c|c|}
\hline Gene & Accession No. & Primer Sequence \\
\hline 18S rRNA & NR_003278.3 & $\begin{array}{l}\text { F: ACCGCGGTTCTATTTTGTTG } \\
\text { R: CCCTCTTAATCATGGCCTCA }\end{array}$ \\
\hline AMPK & NM_001013367.3 & $\begin{array}{l}\text { F: GCTGTGGCTCACCCAATTAT } \\
\text { R: ATCAAAAGGGAGGGTTCCAC }\end{array}$ \\
\hline JNK & NM_016700.4 & $\begin{array}{l}\text { F: CGGAACACCTTGTCCTGAAT } \\
\text { R: GAGTCAGCTGGGAAAAGCAC }\end{array}$ \\
\hline $\mathrm{AKT}$ & NM_001165894.1 & $\begin{array}{l}\text { F: ACTCATTCCAGACCCACGAC } \\
\text { R: GTCCAGGGCAGACACAATCT }\end{array}$ \\
\hline SIRT1 & NM_001159589.2 & $\begin{array}{l}\text { F: AGTTCCAGCCGTCTCTGTGT } \\
\text { R: GATCCTTTGGATTCCTGCAA }\end{array}$ \\
\hline FoxO1 & NM_019739.3 & $\begin{array}{l}\text { F: ACATTTCGTCCTCGAACCAG } \\
\text { R: CAGGTCATCCTGCTCTGTCA }\end{array}$ \\
\hline FoxO3 & NM_019740.3 & $\begin{array}{l}\text { F: ATGGGAGCTTGGAATGTGAC } \\
\text { R: TTAAAATCCAACCCGTCAGC }\end{array}$ \\
\hline SOD2 & NM_013671.3 & $\begin{array}{l}\text { F: CTGTCTTCAGCCACACCAGA } \\
\text { R: CTGCTCTTCCAAAGGTCCTG }\end{array}$ \\
\hline Catalase & NM_009804.2 & $\begin{array}{l}\text { F: TTGACAGAGAGCGGATTCCT } \\
\text { R: TCTGGTGATATCGTGGGTGA }\end{array}$ \\
\hline GPx1 & NM_008160.6 & $\begin{array}{l}\text { F: CCGACCCCAAGTACATCATT } \\
\text { R: CCCACCAGGAACTTCTCAAA }\end{array}$ \\
\hline Bax & NM_007527.3 & $\begin{array}{l}\text { F: ACCAAGAAGCTGAGCGAGTG } \\
\text { R: TGCAGCTCCATATTGCTGTC }\end{array}$ \\
\hline $\mathrm{Bcl} 2$ & NM_009741.5 & $\begin{array}{l}\text { F: ATGATAACCGGGAGATCGTG } \\
\text { R: AGCCCCTCTGTGACAGCTTA }\end{array}$ \\
\hline Caspase3 & NM_001284409.1 & $\begin{array}{l}\text { F: TGTCATCTCGCTCTGGTACG } \\
\text { R: ATTTCAGGCCCATGAATGTC }\end{array}$ \\
\hline
\end{tabular}

F, Forward primer; R, Reverse primer.

\subsection{Intracellular ROS and Glutathione (GSH) Detection}

The levels of intracellular ROS and GSH were measured in BLs from the control, ASC$\mathrm{CM}$, and AMSC-CM groups by staining respectively with $\mathrm{H}_{2}$ DCFDA (2,7'-dichlorodihydrofluorescein diacetate) and CellTracker Blue (4-chloromethyl-6,8-difluoro-7-hydroxycoumarin; $\mathrm{CMF}_{2} \mathrm{HC}$ ). BLs from each group were incubated in $1 \%$ polyvinyl alcohol (PVA)-PBS containing $10 \mu \mathrm{M} \mathrm{H}_{2}$ DCFDA or CellTracker Blue in the dark at $25^{\circ} \mathrm{C}$. After $30 \mathrm{~min}$, BLs were washed and moved to a droplet of PVA-PBS covered with mineral oil. The quantitative 
intensity of fluorescence was evaluated under an epifluorescence microscope (TE2000-S; Nikon, Tokyo, Japan) using filters (ROS: $460 \mathrm{~nm}, \mathrm{GSH}: 370 \mathrm{~nm}$ ) and analyzed by Image J software version 1.52 (National Institutes of Health, Bethesda, MO, USA).

\subsection{Antioxidant Capacity and Enzyme Activity Assays}

The total antioxidant capacity (TAC), superoxide dismutase (SOD), and catalase activity were measured using OxiSelect ${ }^{\mathrm{TM}}$ assay kits (Cell Biolabs Inc., San Diego, CA, USA) according to the manufacturer's protocol. Non-conditioned medium as control, ASC-CM and AMSC-CM were assessed for TAC, SOD, and CAT activity levels. Culture medium of the control, ASC-CM, and AMSC-CM groups before and after IVC were assessed for SOD and CAT activity levels. The results of each colorimetric assay were assessed using measured absorbances at $490 \mathrm{~nm}$ for TAC and SOD activity, and $520 \mathrm{~nm}$ for CAT activity.

\subsection{Mitochondrial Membrane Potential Assay}

BLs from the control, ASC-CM, and AMSC-CM groups were washed in 1\% PVA-PBS and fixed in $4 \%$ paraformaldehyde-PBS for $1 \mathrm{~h}$. After washing in 1\% PVA-PBS, BLs were incubated in 1\% PVA-PBS containing $2 \mu \mathrm{L} \mathrm{JC}-1$ solution (Abcam, Cambridge, UK) and then washed in fresh $1 \%$ PVA-PBS. After $30 \mathrm{~min}$, BLs were placed on a droplet of glycerol on a microscope glass slide with a coverslip. The fluorescence intensity of JC-1 aggregate at $590 \mathrm{~nm}$ and JC-1 monomer at $530 \mathrm{~nm}$ was evaluated using epifluorescence microscope and analyzed using Image J software version 1.52 .

\subsection{Statistical Analysis}

A Kolmogorov-Smirnov test was conducted as normality test. Unpaired $t$-test was used to compare two groups. One-way ANOVA followed by Newman-Keuls or Tukey's post-hoc test and two-way ANOVA test with Bonferroni post-test were used to compare more than two groups. GraphPad Prism version 5 (GraphPad Software, San Diego, CA, USA) was used for statistical analyses. Data are presented as mean \pm standard error of the mean (SEM), and a $p$-value $<0.05$ was considered statistically significant among the groups. All experiments were performed with at least three replicates.

\section{Results}

\subsection{Characterization of AMSC and ASC}

AMSCs were analyzed with flow cytometry to identify the expression of phenotypic markers (Figure 1) and confirmed that AMSCs from all donors were positive for mesenchymal markers (CD73, CD90, CD105, CD29, and CD44), and negative for the endothelial marker (CD31) and hematopoietic markers (CD34 and CD45). The result of ASC characterization was previously described [6].

(a)

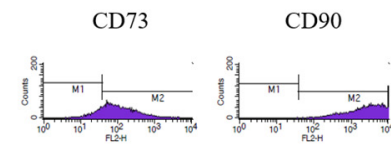

(b)

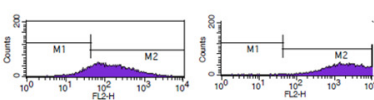

(c)
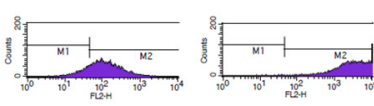

CD105
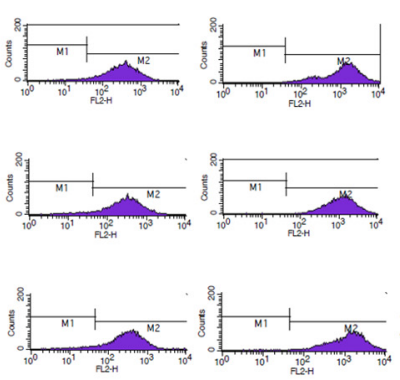
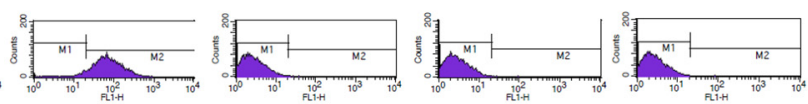

Figure 1. Characterization of human amniotic membrane-derived mesenchymal stem cell (AMSC). AMSCs isolated from three donors $(\mathbf{a}-\mathbf{c})$ were positive for CD73, CD90, CD105, CD29, CD44, and negative for CD31, CD34, and CD45. 


\subsection{Effects of Various Concentrations of AMSC-CM on Embryo Development}

Embryo development to 4-, 16-cell stages, BL, and hatched BL was evaluated to determine the optimal concentration of AMSC-CM supplementation among the three different concentrations of AMSC-CM (10\%, 20\%, and 50\%). As shown in Table 2, embryo development rate to the 4-cell stage was significantly lower in the $50 \%$ AMSC-CM group $(79.6 \pm 4.0)$ than in the control $(91.8 \pm 1.8, p<0.05), 10 \%(92.5 \pm 4.8, p<0.05)$, and $20 \%$ AMSC-CM (93.4 $\pm 3.0, p<0.05)$ groups. Moreover, the embryo development rate to the 16-cell stage was significantly higher in the $10 \%$ AMSC-CM group $(74.3 \pm 4.8)$ than in the $20 \%(61.2 \pm 3.5, p<0.05)$ and $50 \%$ AMSC-CM $(59.5 \pm 3.8, p<0.05)$ groups. The rate of BL formation in the $10 \%$ AMSC-CM group $(51.7 \pm 4.1)$ was significantly higher than that in the control $(38.6 \pm 4.5, p<0.05), 20 \%(30.7 \pm 5.5, p<0.05)$, and 50\% AMSC-CM $(28.3 \pm 6.8, p<0.05)$ groups. BL hatching rate in the 10\% AMSC-CM group $(32.6 \pm 5.9)$ was also significantly higher than that in the control $(19.4 \pm 4.6, p<0.05), 20 \%(19.1 \pm 3.5$, $p<0.05)$, and $50 \%$ AMSC-CM $(18.8 \pm 3.4, p<0.05)$ groups.

Table 2. Effect of human amniotic membrane-derived mesenchymal stem cell conditioned medium (AMSC-CM) on in vitro fertilized mouse embryos development.

\begin{tabular}{|c|c|c|c|c|c|}
\hline \multirow[b]{2}{*}{ Group } & \multirow{2}{*}{$\begin{array}{l}\text { No. of Cultured } \\
\text { Embryos }\end{array}$} & \multicolumn{4}{|c|}{ No. of Embryos Developed to (\%) } \\
\hline & & 4-Cell & 16-Cell & Blastocyst & $\begin{array}{c}\text { Hatched } \\
\text { Blastocyst }\end{array}$ \\
\hline Control & 72 & $66(91.8 \pm 1.8)^{b}$ & $51(71.1 \pm 2.6)^{a b}$ & $28(38.6 \pm 4.5)^{\mathrm{a}}$ & $14(19.4 \pm 4.6)^{\mathrm{a}}$ \\
\hline $10 \%$ AMSC-CM & 74 & $69(92.5 \pm 4.8) b$ & $55(74.3 \pm 4.8)^{b}$ & $39(51.7 \pm 4.1) b$ & $25(32.6 \pm 5.9)^{b}$ \\
\hline $20 \%$ AMSC-CM & 74 & $69(93.4 \pm 3.0)^{b}$ & $45(61.2 \pm 3.5)^{\mathrm{a}}$ & $23(30.7 \pm 5.5)^{a}$ & $15(19.1 \pm 3.5)^{\mathrm{a}}$ \\
\hline $50 \%$ AMSC-CM & 76 & $61(79.6 \pm 4.0)^{\mathrm{a}}$ & $46(59.5 \pm 3.8)^{a}$ & $24(28.3 \pm 6.8)^{a}$ & $16(18.8 \pm 3.4)^{\mathrm{a}}$ \\
\hline
\end{tabular}

Experiments were repeated at least 3 times. ${ }^{a, b}$ Mean \pm SEM with different superscript letters indicate significant differences (at least $p<0.05)$.

\subsection{Comparison of the Effects of ASC-CM and AMSC-CM on Embryo Development}

Following the former experiment, which confirmed $10 \%$ as the optimal concentration of AMSC-CM treatment, the effects of ASC-CM and AMSC-CM during IVC on embryo development to the 4-, 16-cell stages, BL, and hatched BL were compared. As presented in Table 3, the developmental rate of embryos to the 4-cell stage was similar among groups, but the rate to the 16-cell stage was significantly increased in the AMSC-CM group (87.6 \pm 5.1$)$ compared to the control group $(73.7 \pm 3.3, p<0.05)$. In addition, BL formation rate of AMSC-CM group $(65.7 \pm 3.3)$ was significantly higher than that of the control group $(44.4 \pm 5.2, p<0.05)$. The developmental rates of 16-cell and BL in the ASC-CM groups (79.2 \pm 4.0 and $56.4 \pm 2.8$, respectively) showed no difference from those of the other groups. The rate of hatched BL in the AMSC-CM group was greater than that in the other groups, although the difference was not statistically significant.

Table 3. Effect of human adipose-derived mesenchymal stem cell conditioned medium (ASC-CM) and amniotic membranederived mesenchymal stem cell conditioned medium (AMSC-CM) on in vitro fertilized mouse embryos development.

\begin{tabular}{|c|c|c|c|c|c|}
\hline \multirow{2}{*}{ Group } & \multirow{2}{*}{$\begin{array}{l}\text { No. of Cultured } \\
\text { Embryos }\end{array}$} & \multicolumn{4}{|c|}{ Number of Embryos Developed to (\%) } \\
\hline & & 4-Cell & 16-Cell & Blastocyst & $\begin{array}{c}\text { Hatched } \\
\text { Blastocyst }\end{array}$ \\
\hline Control & 135 & $127(93.1 \pm 2.0)$ & $101(73.7 \pm 3.3)^{\mathrm{a}}$ & $62(44.4 \pm 5.2)^{\mathrm{a}}$ & $40(27.4 \pm 8.0)$ \\
\hline ASC-CM & 134 & $124(91.9 \pm 1.7)$ & $108(79.2 \pm 4.0)^{\mathrm{ab}}$ & $76(56.4 \pm 2.8)^{a b}$ & $44(32.2 \pm 4.0)$ \\
\hline AMSC-CM & 130 & $125(95.7 \pm 1.4)$ & $117(87.6 \pm 5.1)^{b}$ & $85(65.7 \pm 3.3)^{b}$ & $53(39.7 \pm 2.8)$ \\
\hline
\end{tabular}

Experiments were repeated at least 3 times. ${ }^{\mathrm{a}, \mathrm{b}}$ Mean \pm SEM with different superscript letters indicate significant differences (at least $p<0.05)$. 


\subsection{Comparative Effects of ASC-CM and AMSC-CM on Antioxidant Gene Expression in BL}

BLs developed in the control, ASC-CM, and AMSC-CM groups were analyzed for the expression of the antioxidant genes in the forkhead box $\mathrm{O}$ (FoxO) pathway and apoptosisrelated genes, as presented in Figure 2. First, the expression of upstream regulators of FoxO was evaluated; the expression of AMP-activated protein kinase (AMPK), c-Jun N-terminal kinase (JNK), and protein kinase $B$ (AKT) exhibited no significant differences among groups. Next, the level of sirtuin (SIRT) 1, a mediator of FoxO, was shown to be significantly higher in the AMSC-CM group $(2.7 \pm 0.4)$ than in the control $(1.0 \pm 0.0, p<0.05)$ and ASC-CM group $(1.4 \pm 0.3, p<0.05)$. FoxO1 and FoxO3 levels were significantly increased in the AMSC-CM group $(3.0 \pm 0.4$ and $2.4 \pm 0.4$, respectively) compared to the control group $(1.0 \pm 0.0, p<0.05)$. Furthermore, FoxO1 expression in the AMSC-CM group $(3.0 \pm 0.4)$ was significantly higher than that in the ASC-CM group $(1.4 \pm 0.2, p<0.05)$ but FoxO3 levels were similar between two groups. The level of SOD2 was significantly greater in the ASC-CM and AMSC-CM groups (2.6 \pm 0.1 and $2.7 \pm 0.1$, respectively) than in the control group (1.0 $\pm 0.0, p<0.05)$. Catalase and glutathione peroxidase (GPx) 1 levels were significantly increased in the AMSC-CM group ( $3.4 \pm 0.6$ and $2.6 \pm 0.2$, respectively) compared to the control $(1.0 \pm 0.0, p<0.05)$ and ASC-CM groups $(1.1 \pm 0.2$ and $1.2 \pm 0.2$, respectively, $p<0.05)$.
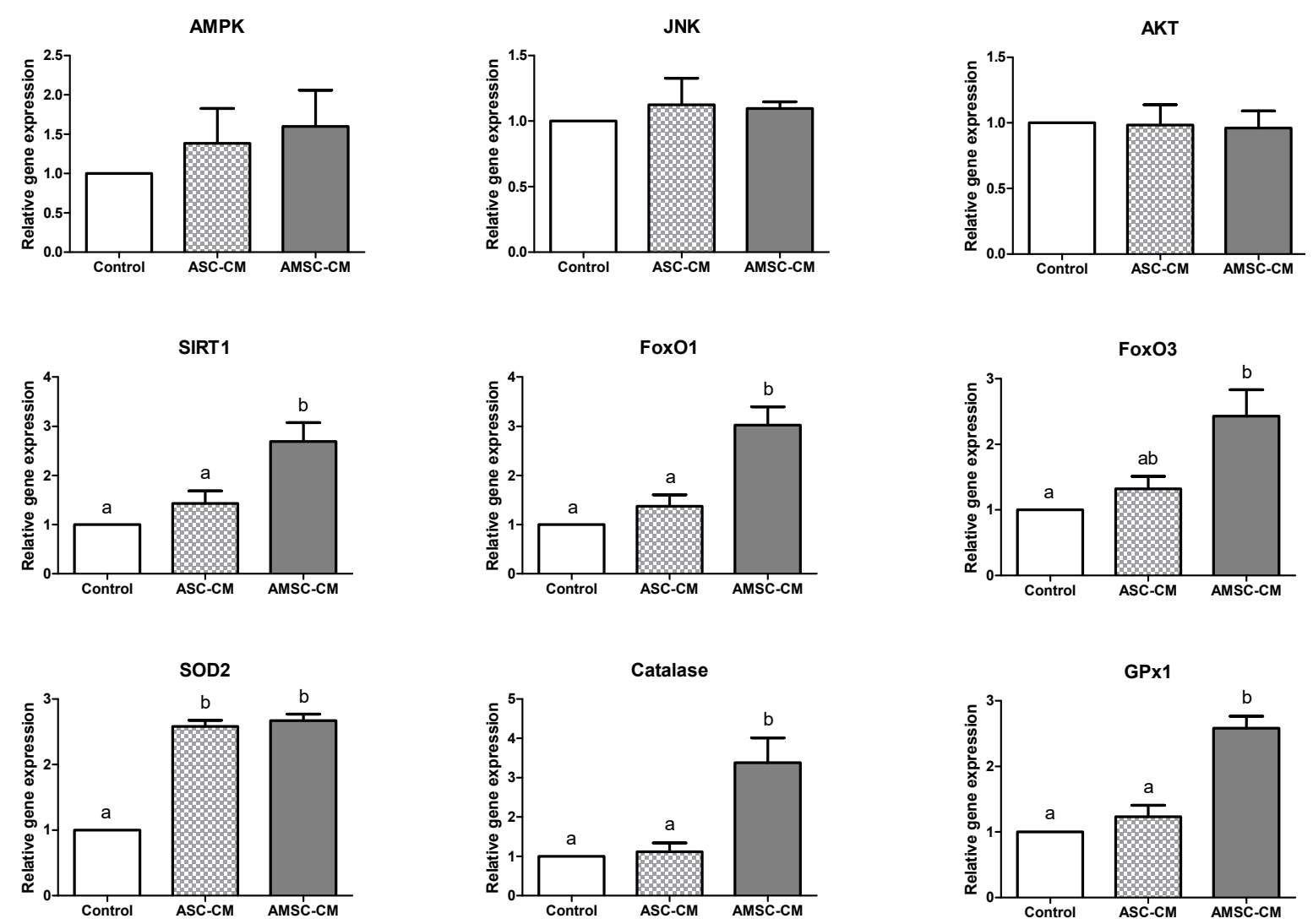

Figure 2. Relative antioxidant gene expression in blastocysts cultured in control, human adipose-derived mesenchymal stem cell conditioned medium (ASC-CM) and amniotic membrane-derived mesenchymal stem cell conditioned medium (AMSC-CM). Data are normalized to housekeeping gene 18S rRNA and presented as mean \pm standard error of the mean (SEM). Superscript letters in each column indicate significant differences $(p<0.05)$.

\subsection{Comparative Effects of ASC-CM and AMSC-CM on Intracellular Oxidative Stress in BL}

Anti-oxidative effects of ASC-CM and AMSC-CM were evaluated through the measurement of ROS and GSH in BL. ROS levels in the BL of the AMSC-CM group $(0.7 \pm 0.1)$ were significantly lower than those in the control group $(1.0 \pm 0.0, p<0.05)$, but the ASC- 
$\mathrm{CM}$ group showed no significant difference with the other groups (Figure 3a). As shown in Figure 3b, GSH levels in the BL in both ASC-CM $(1.2 \pm 0.0)$ and AMSC-CM $(1.3 \pm 0.0)$ groups were significantly increased compared to the control group $(1.0 \pm 0.0, p<0.05)$.

(a)

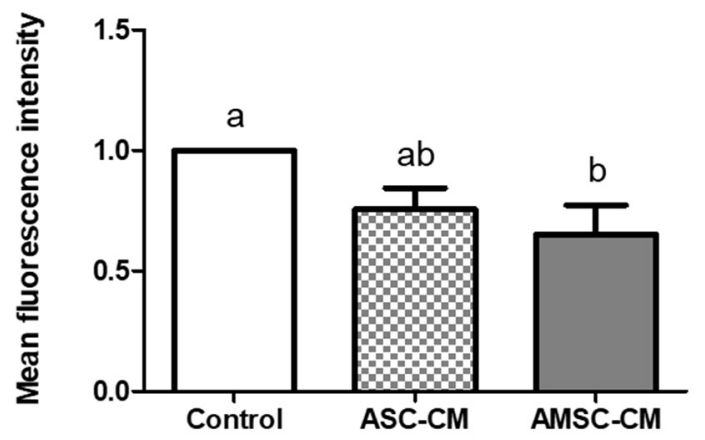

(b)

GSH

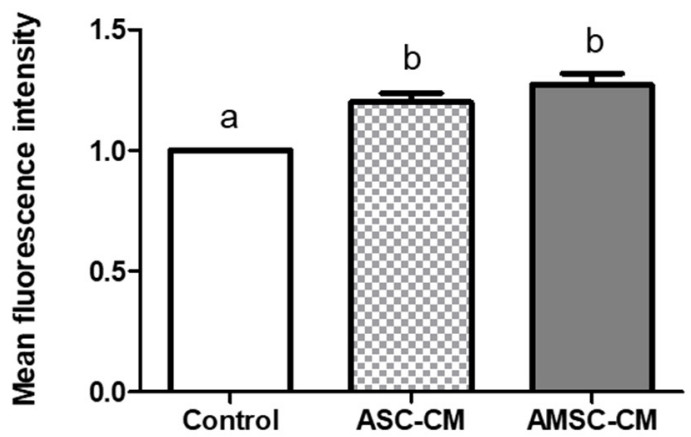

Figure 3. Evaluation of intracellular reactive oxygen species (ROS) and glutathione (GSH) in blastocysts (BL) cultured with human adipose-derived mesenchymal stem cell conditioned medium (ASC-CM) and amniotic membrane-derived mesenchymal stem cell conditioned medium (AMSC-CM). (a) ROS and (b) GSH level in BL. Data are presented as the mean \pm SEM. Superscript letters in each column indicate significant differences $(p<0.05)$.

\subsection{Comparison of Antioxidant Biomarkers in ASC-CM and AMSC-CM}

TAC and SOD activity of both ASC-CM (2.8 \pm 0.2 and $2.6 \pm 0.1)$ and AMSC-CM (7.0 \pm 0.2 and $3.5 \pm 0.2)$ were significantly higher when compared to the control $(1.0 \pm 0.0$ and $1.0 \pm 0.2$, respectively, $p<0.05$, Figure $4 \mathrm{a}, \mathrm{b}$ ). Comparing ASC-CM and AMSC-CM, TAC and SOD activity of AMSC-CM was significantly greater than ASC-CM $(p<0.05$, Figure $4 a, b)$. Catalase activities in ASC-CM $(1.1 \pm 0.0)$ and AMSC-CM $(1.1 \pm 0.0)$ were similar but significantly higher than the control $(1.0 \pm 0.0, p<0.05$, Figure $4 \mathrm{c})$.

(a)

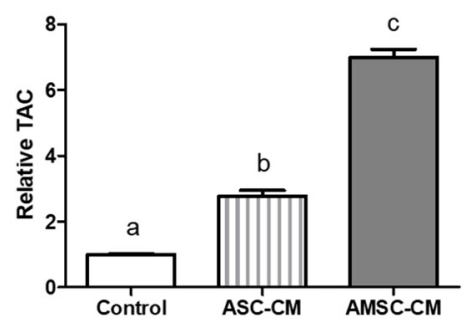

(b)

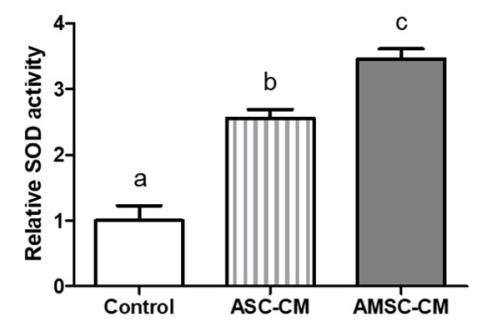

(c)

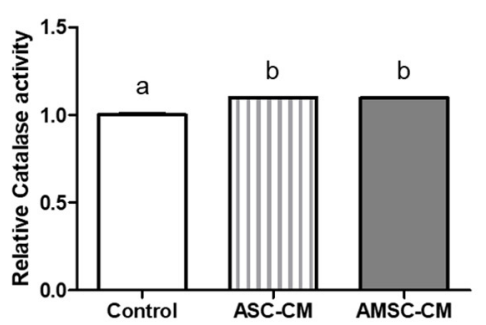

Figure 4. Comparison of antioxidant biomarkers level in human adipose-derived mesenchymal stem cell conditioned medium (ASC-CM) and amniotic membrane-derived mesenchymal stem cell conditioned medium (AMSC-CM). (a) Total antioxidant capacity (TAC), (b) superoxide dismutase (SOD) activity, and (c) catalase activity. Data are normalized to average value of control and presented as the mean \pm SEM. Superscript letters in each column indicate significant differences $(p<0.05)$.

\subsection{Comparison of Antioxidant Biomarkers in Culture Medium with ASC-CM and AMSC-CM}

Catalase activity was significantly increased in pre-IVC medium supplemented with AMSC-CM (1.02 \pm 0.0$)$ compared to the control $(1.0 \pm 0.0, p<0.05)$ and ASC-CM $(1.0 \pm 0.0$, $p<0.05$, Figure 5b). Likewise, SOD activity in post-IVC medium supplemented with AMSC-CM (1.7 \pm 0.2$)$ was significantly greater than that in the control and ASC-CM groups $(1.0 \pm 0.1$ and $1.0 \pm 0.1$, respectively, $p<0.05$, Figure $6 \mathrm{a})$. Furthermore, catalase activity was significantly higher in post-IVC medium supplemented with AMSC-CM 
$(1.0 \pm 0.0)$ than in ASC-CM $(0.9 \pm 0.0, p<0.05$, Figure $6 \mathrm{~b})$ but not when compared to the control.

(a)

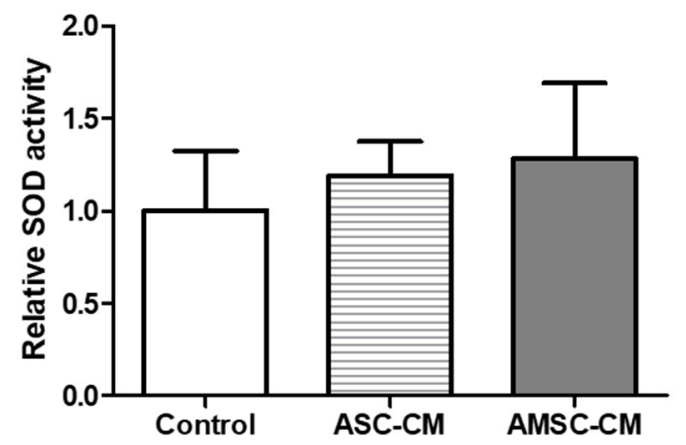

(b)

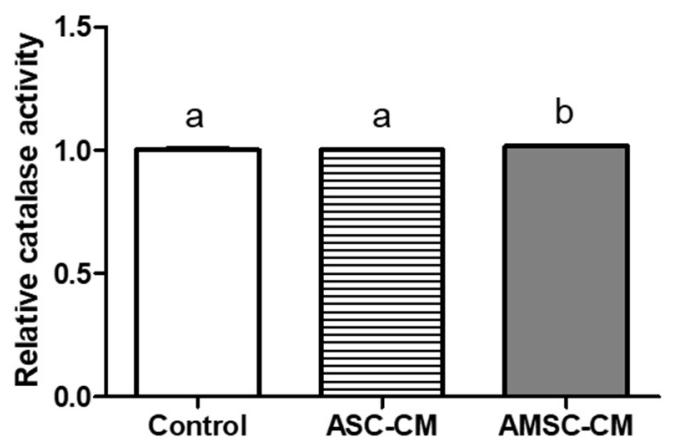

Figure 5. Comparison of antioxidant biomarkers level in fresh culture medium supplemented with human adiposederived mesenchymal stem cell conditioned medium (ASC-CM) and amniotic membrane-derived mesenchymal stem cell conditioned medium (AMSC-CM). (a) Superoxide dismutase (SOD) and (b) catalase activity. Data are normalized to average value of control and presented as the mean \pm SEM. Superscript letters in each column indicate significant differences $(p<0.05)$.

(a)

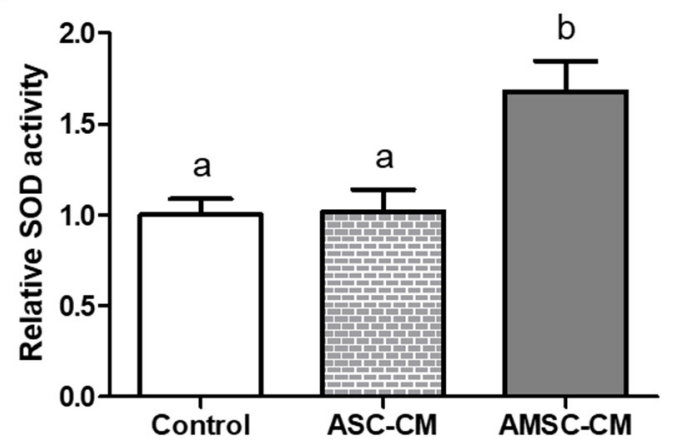

(b)

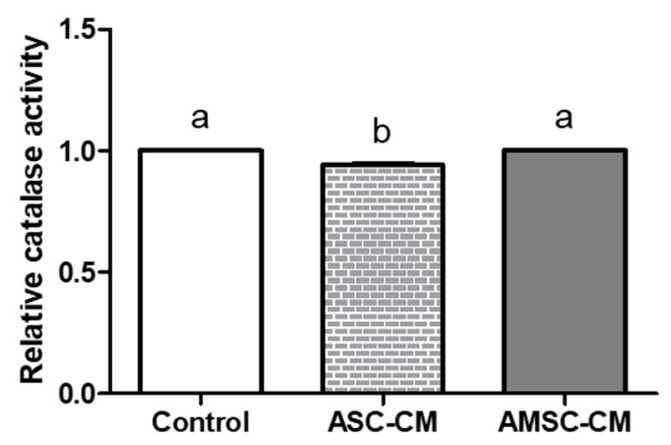

Figure 6. Comparison of antioxidant biomarker levels in culture medium supplemented with human adipose-derived mesenchymal stem cell conditioned medium (ASC-CM) and amniotic membrane-derived mesenchymal stem cell conditioned medium (AMSC-CM) which was collected after 5 days of embryo culture. (a) Superoxide dismutase (SOD) and (b) catalase activity. Data are normalized to average value of control and presented as the mean \pm SEM. Superscript letters in each column indicate significant differences $(p<0.05)$.

\subsection{Comparative Effects of ASC-CM and AMSC-CM on Apoptosis-Related Gene Expression in BL}

To assess not only oxidative stress but also the consequent apoptosis of $\mathrm{BL}$, the relative expression of the anti-apoptotic and pro-apoptotic genes was analyzed. The expression levels of B cell leukemia/lymphoma 2 (Bcl2) in both ASC-CM (1.8 \pm 0.1$)$ and AMSC-CM $(1.7 \pm 0.1)$ groups were significantly greater than those of the control $(1.0 \pm 0.0, p<0.05$, Figure 7). The ratio of Bcl2-associated X (Bax) to Bcl2 expression level in both ASC-CM $(0.5 \pm 0.1)$ and AMSC-CM $(0.3 \pm 0.1)$ groups was significantly lower than those of the control (1.0 $\pm 0.0, p<0.05$, Figure 7). Although no differences were found between the relative gene expression level of Bax among groups, Caspase 3 levels were significantly lower in the AMSC-CM group (0.6 \pm 0.1$)$ than in the ASC-CM group $(1.1 \pm 0.2, p<0.05$, Figure 7). 

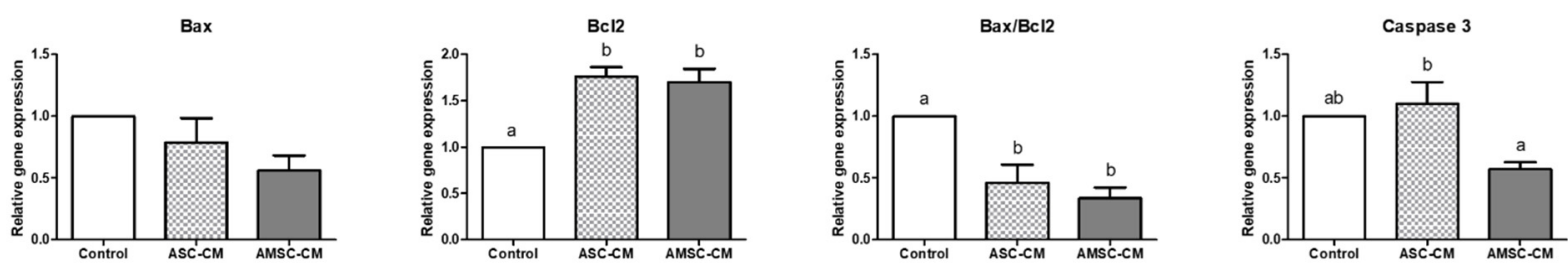

Figure 7. Relative apoptosis-related gene expression in blastocysts cultured in the control, human adipose-derived mesenchymal stem cell conditioned medium (ASC-CM) and amniotic membrane-derived mesenchymal stem cell conditioned medium (AMSC-CM) group. Data are normalized to housekeeping gene $18 \mathrm{~S}$ rRNA and presented as mean \pm standard error of the mean (SEM). Superscript letters in each column indicate significant differences $(p<0.05)$.

\subsection{Comparative Effects of ASC-CM and AMSC-CM on Intracellular Apoptosis in BL}

Mitochondrial membrane potential was visualized and measured as an indicator of intracellular apoptosis using JC-1 fluorescence staining of BLs from the control, ASC-CM, and AMSC-CM groups (Figure 8a). The ratio of JC-1 aggregate to JC-1 monomer in BLs of the AMSC-CM group $(1.3 \pm 0.1)$ was significantly higher than that of the control group $(1.0 \pm 0.0, p<0.05)$. However, the ratio in BLs from the ASC-CM group was similar to that of the other groups (Figure $8 b$ ).

(a)

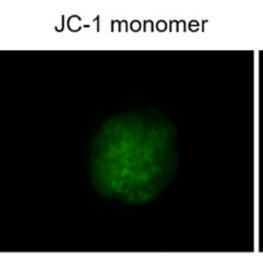

JC-1 aggregate
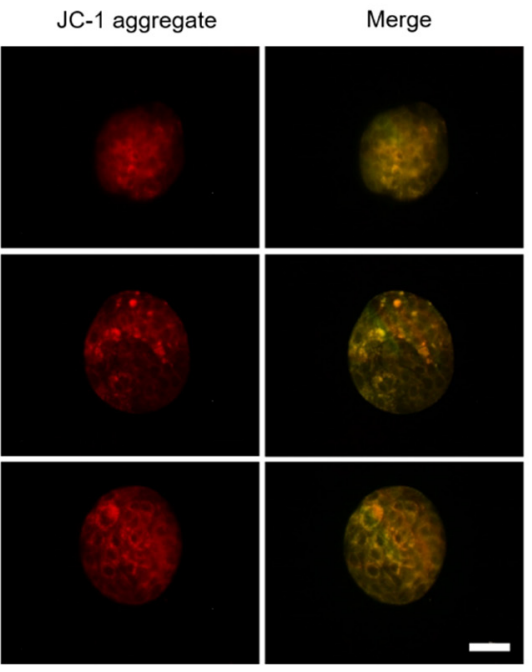

(b)
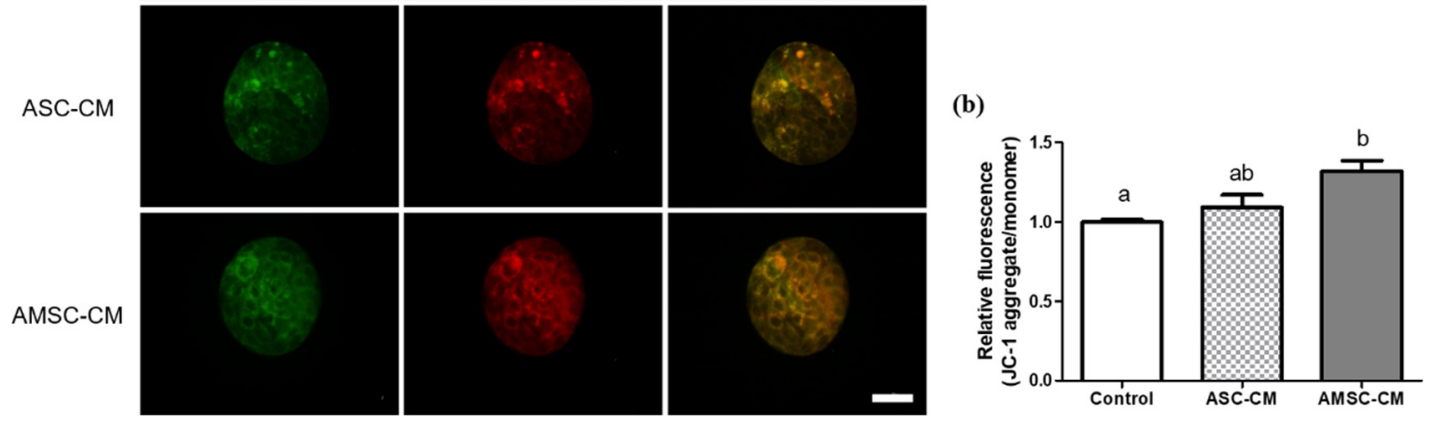

Figure 8. Assessment of mitochondrial membrane potential in blastocysts (BL) cultured with human adipose-derived mesenchymal stem cell conditioned medium (ASC-CM) and amniotic membrane-derived mesenchymal stem cell conditioned medium (AMSC-CM). (a) Representative fluorescent images of JC-1 monomer (green) and aggregate (red) stained BL. Original magnification $400 \times$. Scale bar $=50 \mu \mathrm{m}$. (b) The ratio of JC-1 aggregate (red) to JC-1 monomer (green) presented by quantifying fluorescence intensity of JC-1 mitochondrial membrane potentials in BL. Data are expressed as the mean \pm standard error of the mean (SEM). Superscript letters in each column indicate significant differences $(p<0.05)$.

\section{Discussion}

The present study was conducted with the purpose of (1) examining the anti-oxidative effect of human AMSC-CM treatment during IVC on mouse preimplantation embryo development, while simultaneously evaluating antioxidant gene expression, more specifically, the genes in the FoxO pathway, and (2) comparing human ASC-CM and AMSC-CM as supplementation for mouse embryo culture with regard to their anti-oxidative and anti-apoptotic effects.

At first, the effect of various concentrations of AMSC-CM treatment $(10 \%, 20 \%$, and $50 \%$ ) during IVC was investigated to establish the optimal concentration for the development of in vitro fertilized mouse embryos. The rate of embryos that developed to the 4-cell and 16-cell stage were significantly lower in the 50\% AMSC-CM group than in the $10 \%$ 
AMSC-CM group. These results indicate that a high CM concentration does not ensure better efficiency of embryo development regardless of the large quantity of cytokines as previously explained [6]. Remarkably, we found that 10\% AMSC-CM significantly improved BL formation rate (Table 2), which is an index for embryo developmental potential and consequently determines the success of implantation [41], compared to the control group as well as the other higher concentration of AMSC-CM treated groups. In addition, the 10\% AMSC-CM group showed the most enhanced BL hatching ability, a crucial precondition for successful implantation and pregnancy rates [42]. Together, our results indicated that $10 \%$ AMSC-CM treatment during IVC is optimal for overall preimplantation embryo developmental processes from early cleavage to BL hatching.

A few studies have compared the characteristics and proliferation rate of ASC and AMSC [43-45], but to the best of our knowledge, the comparison between anti-oxidative effects of ASC-CM and AMSC-CM has never been reported, particularly on the embryo and its culture medium. Therefore, the effects of ASC-CM and AMSC-CM treatment at the respective confirmed optimal concentrations in embryo IVC medium were compared. As validated by the results presented in Table 2, AMSC-CM treatment improved embryo development compared to the control. The embryo developmental rate of the AMSC-CM group was greater than that of the ASC-CM group at all the assessed stages (Table 3), but the difference was not statistically significant. The expression of antioxidant genes in the FoxO signaling pathway was analyzed to evaluate the quality of BLs cultured with ASC-CM or AMSC-CM. FoxO transcription factors modulate various cellular functions, including differentiation, growth, metabolism, and apoptosis [46]. These factors predominantly regulate the oxidative stress response by controlling the expression of manganese-dependent SOD (SOD2), catalase, and GPx1 that constitute the primary defense mechanism against ROS [47]. FoxO is considered as a therapeutic target for infertility and is critical for the preimplantation embryo development in mice [46]. Specifically, among the mammalian FoxO family, FoxO1 and FoxO3 are key players in female reproductive processes [48]. We found that the relative expression of FoxO1 and FoxO3 was significantly increased in the BLs cultured with AMSC-CM as compared to those of the control group. Furthermore, the expression levels of SOD2, catalase, and GPx1, downstream targets of the FoxO subfamily, were significantly greater in the AMSC-CM group than in the control group (Figure 2). Remarkably, compared with ASC-CM, AMSC-CM promoted the expression of FoxO1, catalase, and GPx1 (Figure 2). We also analyzed genes that function as upstream regulators of FoxO such as AMPK [49] and JNK [50], as well as AKT [51], but none of the genes exhibited notable differences in expression, which seems to have an ambiguous influence on FoxO activity in that FoxO receives various signals from growth factors, metabolic and oxidative stress [52] and involves numerous mechanisms for its regulation [53]. However, we found an increase in SIRT1 expression in BL cultured with AMSC-CM, which is a crucial regulator of oxidative stress that protects cells by upregulating antioxidant activity through FoxO-dependent mechanisms and, in particular, the interaction of SIRT1 and FOXO3a mainly functions in protecting oocytes against loss of developmental competence from reproductive aging [54]. GSH is a representative non-enzymatic antioxidant that is essential for embryo development after fertilization up to the BL stage [55]. In this study, intracellular GSH levels were increased in BLs with ASC-CM and AMSC-CM treatment, but ROS levels were decreased only in the AMSC-CM group (Figure 3). ROS are attenuated by a collaborative defense system comprising enzymatic and non-enzymatic antioxidants [56]. Collectively, the results described above suggest that AMSC-CM exerts an anti-oxidative effect during embryo culture by improving the expression of both enzymatic and non-enzymatic antioxidants in BL.

We then investigated the antioxidant biomarker activity in CM, pre- and post-IVC medium containing different CM. In addition to TAC, a complex indicator showing the comprehensive activity of various antioxidants [57], the activities of SOD and catalase were all greater in both ASC-CM and AMSC-CM when compared to non-conditioned medium (Figure 4). Notably, we found evident difference that AMSC-CM showed greater level of 
antioxidant biomarkers than ASC-CM. The results are consistent with various studies that reported the factors secreted from MSC contain antioxidants as one of the predominant elements, which are included in CM and exert anti-oxidative effects in paracrine mechanisms [13,58-60]. In particular, numerous growth factors found in CM of human amnion tissue and AMSC [61] have been identified to function as antioxidants including insulin-like growth factor [62], platelet-derived growth factor [63], epidermal growth factor [64], hepatocyte growth factor [65] and fibroblast growth factor [66]. Moreover, pre- and post-IVC medium analysis revealed that the activities of SOD and catalase were higher in culture medium supplemented with AMSC-CM than the medium with ASC-CM (Figures 5 and 6). Therefore, the improvement in embryo developmental rate and antioxidant expression in BLs could be explained by the favorable culture conditions from the active antioxidants in AMSC-CM.

In addition, apoptosis, which is generally accompanied by oxidative damage, was evaluated in BLs. The anti-apoptotic effect of AMSC-CM was confirmed in that pro-apoptotic gene expression was decreased and anti-apoptotic gene expression was increased. More specifically, an upregulation of the anti-apoptotic gene $\mathrm{Bcl} 2$ was observed not only in the AMSC-CM group, but also in the ASC-CM group, indicating that both CMs have antiapoptotic effects. However, Caspase 3 which is known as an apoptosis executioner [67] was downregulated in the AMSC-CM group compared to the ASC-CM group (Figure 7). The caspase signaling pathway is activated by apoptosis-inducing factors released from the mitochondrial intermembrane space to the cytoplasm following the decrease of mitochondrial membrane potential, which is induced by oxidative damage in cells [68]. The effect of ASC-CM on mitochondrial membrane potential was not significant; however, as predicted, the ratio of JC-1 aggregate to JC-1 monomer was found to be higher in BLs cultured with AMSC-CM than in the control (Figure 8), indicating both anti-oxidative and anti-apoptotic effects of AMSC-CM on in vitro produced BL with enhanced mitochondrial membrane potential.

The present study compared antioxidant competence of CM obtained from two different types of MSC, ASC-CM and AMSC-CM, and suggested that AMSC-CM may be more efficient for embryo culture rather than ASC-CM. Our findings are supported by previous studies demonstrating that the quantity and variety of secretome from MSC can alter depending on different tissue sources of origin $[29,69,70]$. A point to be considered is that, to date, it is uncertain that MSC-CM can outperform chemical antioxidant compounds. To cite an example, several studies indicated that resveratrol, one of the chemically defined antioxidants which has been extensively studied [71], achieved less effective outcomes than MSC in pathological condition and diseases related to oxidative damage [72-74]. However, a direct comparison of MSC-CM and other antioxidant compounds has never been conducted to the best of our knowledge, especially in terms of assisted reproduction, and further studies are expected for clarification.

\section{Conclusions}

In conclusion, this study established that AMSC-CM treatment, at the optimal concentration, acts as an antioxidant during IVC of mouse preimplantation embryos. Furthermore, AMSC-CM treatment had a beneficial effect on embryo developmental rate and upregulated the FoxO-mediated expression of antioxidant enzymes in BLs cultured with AMSCCM. Compared with ASC-CM, as a conventional antioxidant, AMSC-CM demonstrated enhanced expression of both enzymatic and non-enzymatic antioxidants, promotion of anti-oxidative culture conditions, and anti-apoptotic effects on developed embryos. These findings indicate that AMSC-CM can be developed as a novel and competent antioxidant interventions for the improvement of assisted reproductive technologies.

Supplementary Materials: The following are available online at https:/ / www.mdpi.com/2076-392 1/10/2/268/s1, Table S1: Analysis of the quantity and quality of the extracted RNA. 
Author Contributions: Conceptualization, K.R., H.J.O., E.Y.K., S.K.K. and J.C.R.; Data curation, K.R.; Formal analysis, K.R.; Funding acquisition, S.C.P. and B.C.L.; Investigation, K.R., E.Y.K., and E.H.K.; Methodology, K.R. and H.J.O.; Project administration, S.K.K., J.C.R., S.C.P. and B.C.L.; Resources, J.C.R., S.C.P. and B.C.L.; Supervision, S.C.P. and B.C.L.; Validation, S.C.P. and B.C.L.; Visualization, K.R.; Writing-original draft, K.R.; Writing—review and editing, K.R. All authors have read and agreed to the published version of the manuscript.

Funding: This research was supported by Nature Cell (\#550-20170028, \#550-20200076) and the BK21 plus program, and Research Institute for Veterinary Science.

Institutional Review Board Statement: The study was conducted according to the guidelines of the Declaration of Helsinki, and approved by the Ethics Committee of Biostar Stem Cell Technology (IRB NO. 2019-03). All experiments using experimental animals in this study were approved by the Institutional Animal Care and Use Committee of Seoul National University (SNU-170511-2-4).

Informed Consent Statement: Informed consent was obtained from all subjects involved in the study.

Conflicts of Interest: K.R., H.J.O., E.H.K., S.C.P. and B.C.L. declare that they have no conflict of interest. E.Y.K., S.K.K. and J.C.R. have been employees of Nature Cell and declare no intervention in data analysis, interpretation and presentation as stated in author contributions. All authors never inappropriately influence or bias the results of this study.

\section{References}

1. Chronopoulou, E.; Harper, J.C. IVF culture media: Past, present and future. Hum. Reprod. Update 2015, 21, 39-55. [CrossRef]

2. Agarwal, A.; Allamaneni, S.S. Role of free radicals in female reproductive diseases and assisted reproduction. Reprod. Biomed. Online 2004, 9, 338-347. [CrossRef]

3. Du Plessis, S.S.; Makker, K.; Desai, N.R.; Agarwal, A. Impact of oxidative stress on IVF. Expert Rev. Obstet. Gynecol. 2008, 3, 539-554. [CrossRef]

4. Yang, H.W.; Hwang, K.J.; Kwon, H.C.; Kim, H.S.; Choi, K.W.; Oh, K.S. Detection of reactive oxygen species (ROS) and apoptosis in human fragmented embryos. Hum. Reprod. 1998, 13, 998-1002. [CrossRef] [PubMed]

5. Oyawoye, O.; Abdel Gadir, A.; Garner, A.; Constantinovici, N.; Perrett, C.; Hardiman, P. Antioxidants and reactive oxygen species in follicular fluid of women undergoing IVF: Relationship to outcome. Hum. Reprod. 2003, 18, 2270-2274. [CrossRef]

6. Ra, K.; Oh, H.J.; Kim, E.Y.; Kang, S.K.; Ra, J.C.; Kim, E.H.; Lee, B.C. Anti-Oxidative Effects of Human Adipose Stem Cell Conditioned Medium with Different Basal Medium during Mouse Embryo In Vitro Culture. Animals 2020, 10, 1414. [CrossRef]

7. Agarwal, A.; Said, T.M.; Bedaiwy, M.A.; Banerjee, J.; Alvarez, J.G. Oxidative stress in an assisted reproductive techniques setting. Fertil. Steril. 2006, 86, 503-512. [CrossRef]

8. Cambra, J.M.; Martinez, C.A.; Rodriguez-Martinez, H.; Martinez, E.A.; Cuello, C.; Gil, M.A. N-(2-mercaptopropionyl)-glycine enhances in vitro pig embryo production and reduces oxidative stress. Sci. Rep. 2020, 10, 18632. [CrossRef] [PubMed]

9. Wang, X.; Falcone, T.; Attaran, M.; Goldberg, J.M.; Agarwal, A.; Sharma, R.K. Vitamin C and vitamin E supplementation reduce oxidative stress-induced embryo toxicity and improve the blastocyst development rate. Fertil. Steril. 2002, 78, 1272-1277. [CrossRef]

10. Abdelrazik, H.; Sharma, R.; Mahfouz, R.; Agarwal, A. L-carnitine decreases DNA damage and improves the in vitro blastocyst development rate in mouse embryos. Fertil. Steril. 2009, 91, 589-596. [CrossRef] [PubMed]

11. Wang, F.; Tian, X.; Zhang, L.; He, C.; Ji, P.; Li, Y.; Tan, D.; Liu, G. Beneficial effect of resveratrol on bovine oocyte maturation and subsequent embryonic development after in vitro fertilization. Fertil. Steril. 2014, 101, 577-586. [CrossRef] [PubMed]

12. Gruber, I.; Klein, M. Embryo culture media for human IVF: Which possibilities exist? J. Turk. Ger. Gynecol. Assoc. 2011, 12, 110-117. [CrossRef] [PubMed]

13. Stavely, R.; Nurgali, K. The emerging antioxidant paradigm of mesenchymal stem cell therapy. Stem Cells Transl. Med. 2020, 9 , 985-1006. [CrossRef]

14. Ullah, I.; Subbarao, R.B.; Rho, G.J. Human mesenchymal stem cells—Current trends and future prospective. Biosci. Rep. 2015, 35. [CrossRef]

15. Pittenger, M.F.; Discher, D.E.; Peault, B.M.; Phinney, D.G.; Hare, J.M.; Caplan, A.I. Mesenchymal stem cell perspective: Cell biology to clinical progress. NPJ Regen. Med. 2019, 4, 22. [CrossRef]

16. Kim, W.S.; Park, B.S.; Sung, J.H. The wound-healing and antioxidant effects of adipose-derived stem cells. Expert Opin. Biol. Ther. 2009, 9, 879-887. [CrossRef]

17. Kim, W.S.; Park, B.S.; Kim, H.K.; Park, J.S.; Kim, K.J.; Choi, J.S.; Chung, S.J.; Kim, D.D.; Sung, J.H. Evidence supporting antioxidant action of adipose-derived stem cells: Protection of human dermal fibroblasts from oxidative stress. J. Dermatol. Sci. 2008, 49, 133-142. [CrossRef] 
18. Ra, K.; Oh, H.J.; Kim, G.A.; Kang, S.K.; Ra, J.C.; Lee, B.C. High Frequency of Intravenous Injection of Human Adipose Stem Cell Conditioned Medium Improved Embryo Development of Mice in Advanced Maternal Age through Antioxidant Effects. Animals 2020, 10, 978. [CrossRef]

19. Toda, A.; Okabe, M.; Yoshida, T.; Nikaido, T. The potential of amniotic membrane/amnion-derived cells for regeneration of various tissues. J. Pharmacol. Sci. 2007, 105, 215-228. [CrossRef]

20. Kim, E.Y.; Lee, K.B.; Kim, M.K. The potential of mesenchymal stem cells derived from amniotic membrane and amniotic fluid for neuronal regenerative therapy. BMB Rep. 2014, 47, 135-140. [CrossRef] [PubMed]

21. Diaz-Prado, S.; Muinos-Lopez, E.; Hermida-Gomez, T.; Rendal-Vazquez, M.E.; Fuentes-Boquete, I.; de Toro, F.J.; Blanco, F.J. Multilineage differentiation potential of cells isolated from the human amniotic membrane. J. Cell Biochem. 2010, 111, 846-857. [CrossRef]

22. Abbasi-Kangevari, M.; Ghamari, S.H.; Safaeinejad, F.; Bahrami, S.; Niknejad, H. Potential Therapeutic Features of Human Amniotic Mesenchymal Stem Cells in Multiple Sclerosis: Immunomodulation, Inflammation Suppression, Angiogenesis Promotion, Oxidative Stress Inhibition, Neurogenesis Induction, MMPs Regulation, and Remyelination Stimulation. Front. Immunol. 2019, 10, 238. [CrossRef]

23. Bulati, M.; Miceli, V.; Gallo, A.; Amico, G.; Carcione, C.; Pampalone, M.; Conaldi, P.G. The Immunomodulatory Properties of the Human Amnion-Derived Mesenchymal Stromal/Stem Cells Are Induced by INF-gamma Produced by Activated Lymphomonocytes and Are Mediated by Cell-To-Cell Contact and Soluble Factors. Front. Immunol. 2020, 11, 54. [CrossRef]

24. Wang, Y.; Ma, J.; Du, Y.; Miao, J.; Chen, N. Human Amnion-Derived Mesenchymal Stem Cells Protect Human Bone Marrow Mesenchymal Stem Cells against Oxidative Stress-Mediated Dysfunction via ERK1/2 MAPK Signaling. Mol. Cells 2016, 39, 186-194. [CrossRef]

25. He, F.; Wang, Y.; Li, Y.; Yu, L. Human amniotic mesenchymal stem cells alleviate paraquat-induced pulmonary fibrosis in rats by inhibiting the inflammatory response. Life Sci. 2020, 243, 117290. [CrossRef]

26. Xie, C.; Jin, J.; Lv, X.; Tao, J.; Wang, R.; Miao, D. Anti-aging Effect of Transplanted Amniotic Membrane Mesenchymal Stem Cells in a Premature Aging Model of Bmi-1 Deficiency. Sci. Rep. 2015, 5, 13975. [CrossRef] [PubMed]

27. Jiao, H.; Shi, K.; Zhang, W.; Yang, L.; Yang, L.; Guan, F.; Yang, B. Therapeutic potential of human amniotic membrane-derived mesenchymal stem cells in APP transgenic mice. Oncol. Lett. 2016, 12, 1877-1883. [CrossRef] [PubMed]

28. Li, J.Y.; Ren, K.K.; Zhang, W.J.; Xiao, L.; Wu, H.Y.; Liu, Q.Y.; Ding, T.; Zhang, X.C.; Nie, W.J.; Ke, Y.; et al. Human amniotic mesenchymal stem cells and their paracrine factors promote wound healing by inhibiting heat stress-induced skin cell apoptosis and enhancing their proliferation through activating PI3K/AKT signaling pathway. Stem Cell Res. Ther. 2019, 10, 247. [CrossRef] [PubMed]

29. Kusuma, G.D.; Carthew, J.; Lim, R.; Frith, J.E. Effect of the Microenvironment on Mesenchymal Stem Cell Paracrine Signaling: Opportunities to Engineer the Therapeutic Effect. Stem Cells Dev. 2017, 26, 617-631. [CrossRef]

30. Pawitan, J.A. Prospect of stem cell conditioned medium in regenerative medicine. Biomed. Res. Int. 2014, 2014, 965849. [CrossRef]

31. Sagaradze, G.; Grigorieva, O.; Nimiritsky, P.; Basalova, N.; Kalinina, N.; Akopyan, Z.; Efimenko, A. Conditioned Medium from Human Mesenchymal Stromal Cells: Towards the Clinical Translation. Int. J. Mol. Sci. 2019, 20, 1656. [CrossRef] [PubMed]

32. Simopoulou, M.; Sfakianoudis, K.; Rapani, A.; Giannelou, P.; Anifandis, G.; Bolaris, S.; Pantou, A.; Lambropoulou, M.; Pappas, A.; Deligeoroglou, E.; et al. Considerations Regarding Embryo Culture Conditions: From Media to Epigenetics. In Vivo 2018, 32 , 451-460. [CrossRef] [PubMed]

33. Leese, H.J.; Baumann, C.G.; Brison, D.R.; McEvoy, T.G.; Sturmey, R.G. Metabolism of the viable mammalian embryo: Quietness revisited. Mol. Hum. Reprod. 2008, 14, 667-672. [CrossRef] [PubMed]

34. Eisenbach, M.; Giojalas, L.C. Sperm guidance in mammals-An unpaved road to the egg. Nat. Rev. Mol. Cell Biol. 2006, 7, 276-285. [CrossRef]

35. Baak, N.A.; Cantineau, A.E.; Farquhar, C.; Brison, D.R. Temperature of embryo culture for assisted reproduction. Cochrane Database Syst. Rev. 2019, 9, CD012192. [CrossRef]

36. Higdon, H.L., 3rd; Blackhurst, D.W.; Boone, W.R. Incubator management in an assisted reproductive technology laboratory. Fertil. Steril. 2008, 89, 703-710. [CrossRef]

37. Muller, W.U. Temperature dependence of combined exposure of preimplantation mouse embryos to X-rays and mercury. Radiat. Environ. Biophys. 1990, 29, 109-114. [CrossRef]

38. Morbeck, D.E.; Paczkowski, M.; Fredrickson, J.R.; Krisher, R.L.; Hoff, H.S.; Baumann, N.A.; Moyer, T.; Matern, D. Composition of protein supplements used for human embryo culture. J. Assist. Reprod. Genet. 2014, 31, 1703-1711. [CrossRef] [PubMed]

39. Hayashi, M.; Yoshida, K.; Kitada, K.; Kizu, A.; Tachibana, D.; Fukui, M.; Morita, T.; Koyama, M. Low-dose irradiation of mouse embryos increases Smad-p21 pathway activity and preserves pluripotency. J. Assist. Reprod. Genet. 2018, 35, 1061-1069. [CrossRef]

40. Edwards, L.J.; Kind, K.L.; Armstrong, D.T.; Thompson, J.G. Effects of recombinant human follicle-stimulating hormone on embryo development in mice. Am. J. Physiol. Endocrinol. Metab. 2005, 288, E845-E851. [CrossRef]

41. Zhang, S.; Lin, H.; Kong, S.; Wang, S.; Wang, H.; Wang, H.; Armant, D.R. Physiological and molecular determinants of embryo implantation. Mol. Aspects Med. 2013, 34, 939-980. [CrossRef]

42. Hammadeh, M.E.; Fischer-Hammadeh, C.; Ali, K.R. Assisted hatching in assisted reproduction: A state of the art. J. Assist. Reprod. Genet. 2011, 28, 119-128. [CrossRef] 
43. Hwang, I.S.; Kim, H.G.; Jo, D.H.; Lee, D.H.; Koo, Y.H.; Song, Y.J.; Na, Y.J.; Choi, O.H. Comparison with human amniotic membrane- and adipose tissue-derived mesenchymal stem cells. Korean J. Obstet. Gynecol. 2011, 54, 674-683. [CrossRef]

44. Kim, D.; Kyung, J.; Park, D.; Choi, E.K.; Kim, K.S.; Shin, K.; Lee, H.; Shin, I.S.; Kang, S.K.; Ra, J.C.; et al. Health Span-Extending Activity of Human Amniotic Membrane- and Adipose Tissue-Derived Stem Cells in F344 Rats. Stem Cells Transl. Med. 2015, 4, 1144-1154. [CrossRef]

45. Dizaji Asl, K.; Shafaei, H.; Soleimani Rad, J.; Nozad, H.O. Comparison of Characteristics of Human Amniotic Membrane and Human Adipose Tissue Derived Mesenchymal Stem Cells. World J. Plast. Surg. 2017, 6, 33-39.

46. Kuscu, N.; Gungor-Ordueri, N.E.; Sozen, B.; Adiguzel, D.; Celik-Ozenci, C. FoxO transcription factors 1 regulate mouse preimplantation embryo development. J. Assist. Reprod. Genet. 2019, 36, 2121-2133. [CrossRef] [PubMed]

47. Lu, J.; Wang, Z.; Cao, J.; Chen, Y.; Dong, Y. A novel and compact review on the role of oxidative stress in female reproduction. Reprod. Biol. Endocrinol. 2018, 16, 80. [CrossRef]

48. Wang, Y.; Zhou, Y.; Graves, D.T. FOXO transcription factors: Their clinical significance and regulation. Biomed. Res. Int. 2014, 2014, 925350. [CrossRef] [PubMed]

49. Greer, E.L.; Oskoui, P.R.; Banko, M.R.; Maniar, J.M.; Gygi, M.P.; Gygi, S.P.; Brunet, A. The energy sensor AMP-activated protein kinase directly regulates the mammalian FOXO3 transcription factor. J. Biol. Chem. 2007, 282, 30107-30119. [CrossRef]

50. Essers, M.A.; Weijzen, S.; de Vries-Smits, A.M.; Saarloos, I.; de Ruiter, N.D.; Bos, J.L.; Burgering, B.M. FOXO transcription factor activation by oxidative stress mediated by the small GTPase Ral and JNK. EMBO J. 2004, 23, 4802-4812. [CrossRef]

51. Brunet, A.; Bonni, A.; Zigmond, M.J.; Lin, M.Z.; Juo, P.; Hu, L.S.; Anderson, M.J.; Arden, K.C.; Blenis, J.; Greenberg, M.E. Akt promotes cell survival by phosphorylating and inhibiting a Forkhead transcription factor. Cell 1999, 96, 857-868. [CrossRef]

52. Fasano, C.; Disciglio, V.; Bertora, S.; Lepore Signorile, M.; Simone, C. FOXO3a from the Nucleus to the Mitochondria: A Round Trip in Cellular Stress Response. Cells 2019, 8, 1110. [CrossRef] [PubMed]

53. Brown, A.K.; Webb, A.E. Regulation of FOXO Factors in Mammalian Cells. Curr. Top. Dev. Biol. 2018, 127, 165-192. [CrossRef] [PubMed]

54. Tatone, C.; Di Emidio, G.; Vitti, M.; Di Carlo, M.; Santini, S., Jr.; D’Alessandro, A.M.; Falone, S.; Amicarelli, F. Sirtuin Functions in Female Fertility: Possible Role in Oxidative Stress and Aging. Oxid. Med. Cell Longev. 2015, 2015, 659687. [CrossRef]

55. Salmen, J.J.; Skufca, F.; Matt, A.; Gushansky, G.; Mason, A.; Gardiner, C.S. Role of glutathione in reproductive tract secretions on mouse preimplantation embryo development. Biol. Reprod. 2005, 73, 308-314. [CrossRef]

56. Khazaei, M.; Aghaz, F. Reactive Oxygen Species Generation and Use of Antioxidants during In Vitro Maturation of Oocytes. Int. J. Fertil. Steril. 2017, 11, 63-70. [CrossRef]

57. Zhang, T.; Andrukhov, O.; Haririan, H.; Muller-Kern, M.; Liu, S.; Liu, Z.; Rausch-Fan, X. Total Antioxidant Capacity and Total Oxidant Status in Saliva of Periodontitis Patients in Relation to Bacterial Load. Front. Cell Infect. Microbiol. 2015, 5, 97. [CrossRef]

58. Baraniak, P.R.; McDevitt, T.C. Stem cell paracrine actions and tissue regeneration. Regen. Med. 2010, 5, 121-143. [CrossRef]

59. Maguire, G. Stem cell therapy without the cells. Commun. Integr. Biol. 2013, 6, e26631. [CrossRef]

60. Gunawardena, T.N.A.; Rahman, M.T.; Abdullah, B.J.J.; Abu Kasim, N.H. Conditioned media derived from mesenchymal stem cell cultures: The next generation for regenerative medicine. J. Tissue Eng. Regen. Med. 2019, 13, 569-586. [CrossRef]

61. Grzywocz, Z.; Pius-Sadowska, E.; Klos, P.; Gryzik, M.; Wasilewska, D.; Aleksandrowicz, B.; Dworczynska, M.; Sabalinska, S.; Hoser, G.; Machalinski, B.; et al. Growth factors and their receptors derived from human amniotic cells in vitro. Folia Histochem. Cytobiol. 2014, 52, 163-170. [CrossRef] [PubMed]

62. Garcia-Fernandez, M.; Castilla-Cortazar, I.; Diaz-Sanchez, M.; Navarro, I.; Puche, J.E.; Castilla, A.; Casares, A.D.; Clavijo, E.; Gonzalez-Baron, S. Antioxidant effects of insulin-like growth factor-I (IGF-I) in rats with advanced liver cirrhosis. BMC Gastroenterol. 2005, 5, 7. [CrossRef] [PubMed]

63. Goksen, S.; Balabanli, B.; Coskun-Cevher, S. Application of platelet derived growth factor-BB and diabetic wound healing: The relationship with oxidative events. Free Radic. Res. 2017, 51, 498-505. [CrossRef] [PubMed]

64. Kalay, Z.; Cevher, S.C. Oxidant and antioxidant events during epidermal growth factor therapy to cutaneous wound healing in rats. Int. Wound J. 2012, 9, 362-371. [CrossRef]

65. Santangelo, C.; Matarrese, P.; Masella, R.; Di Carlo, M.C.; Di Lillo, A.; Scazzocchio, B.; Vecci, E.; Malorni, W.; Perfetti, R.; Anastasi, E. Hepatocyte growth factor protects rat RINm5F cell line against free fatty acid-induced apoptosis by counteracting oxidative stress. J. Mol. Endocrinol. 2007, 38, 147-158. [CrossRef] [PubMed]

66. Wei, T.; Shu, Q.; Ning, J.; Wang, S.; Li, C.; Zhao, L.; Zheng, H.; Gao, H. The Protective Effect of Basic Fibroblast Growth Factor on Diabetic Nephropathy Through Remodeling Metabolic Phenotype and Suppressing Oxidative Stress in Mice. Front. Pharmacol. 2020, 11, 66. [CrossRef]

67. Mcllwain, D.R.; Berger, T.; Mak, T.W. Caspase functions in cell death and disease. Cold Spring Harb. Perspect. Biol. 2013, 5, a008656. [CrossRef]

68. Rigoulet, M.; Yoboue, E.D.; Devin, A. Mitochondrial ROS generation and its regulation: Mechanisms involved in $\mathrm{H}_{2} \mathrm{O}_{2}$ signaling. Antioxid. Redox. Signal. 2011, 14, 459-468. [CrossRef]

69. Amable, P.R.; Teixeira, M.V.; Carias, R.B.; Granjeiro, J.M.; Borojevic, R. Protein synthesis and secretion in human mesenchymal cells derived from bone marrow, adipose tissue and Wharton's jelly. Stem Cell Res. Ther. 2014, 5, 53. [CrossRef]

70. Pires, A.O.; Mendes-Pinheiro, B.; Teixeira, F.G.; Anjo, S.I.; Ribeiro-Samy, S.; Gomes, E.D.; Serra, S.C.; Silva, N.A.; Manadas, B.; Sousa, N.; et al. Unveiling the Differences of Secretome of Human Bone Marrow Mesenchymal Stem Cells, Adipose Tissue- 
Derived Stem Cells, and Human Umbilical Cord Perivascular Cells: A Proteomic Analysis. Stem Cells Dev. 2016, 25, $1073-1083$. [CrossRef]

71. Pervaiz, S.; Holme, A.L. Resveratrol: Its biologic targets and functional activity. Antioxid. Redox. Signal. 2009, 11, 2851-2897. [CrossRef] [PubMed]

72. Pinarli, F.A.; Turan, N.N.; Pinarli, F.G.; Okur, A.; Sonmez, D.; Ulus, T.; Oguz, A.; Karadeniz, C.; Delibasi, T. Resveratrol and adipose-derived mesenchymal stem cells are effective in the prevention and treatment of doxorubicin cardiotoxicity in rats. Pediatr. Hematol. Oncol. 2013, 30, 226-238. [CrossRef] [PubMed]

73. Okay, E.; Simsek, T.; Subasi, C.; Gunes, A.; Duruksu, G.; Gurbuz, Y.; Gacar, G.; Karaoz, E. Cross effects of resveratrol and mesenchymal stem cells on liver regeneration and homing in partially hepatectomized rats. Stem Cell Rev. Rep. 2015, 11, 322-331. [CrossRef] [PubMed]

74. Xian, Y.; Lin, Y.; Cao, C.; Li, L.; Wang, J.; Niu, J.; Guo, Y.; Sun, Y.; Wang, Y.; Wang, W. Protective effect of umbilical cord mesenchymal stem cells combined with resveratrol against renal podocyte damage in NOD mice. Diabetes Res. Clin. Pract. 2019, 156, 107755. [CrossRef] 